\section{VANCOMYCIN RESISTANT ENTEROCOCCUS SPP (VRE): Follow UP DURING 9 YEARS IN A TERTIARY TEACHING HOSPITAL IN SOUTHERN BRAZIL}

\author{
Ana Maria Sandri ${ }^{1}$, Geórgia Lopes da Silva², Sílvia Pedroso Tavares \\ Soares ${ }^{2}$, Fabiano Ramos ${ }^{1,2}$, Luciana Ruschel de Alcântara ${ }^{3}$, Larissa \\ Lutz ${ }^{4}$, Afonso Luís Barth ${ }^{5}$
}

\section{ABSTRACT}

Introduction: Infection with vancomycin-resistant Enterococcus spp (VRE) has been a worldwide problem since mid 1980's and, in Brazil, since 1996. This study was conducted to evaluate the experience with VRE in our institution.

Methods: A prospective cohort study from 2000 to 2009 was conducted at Hospital São Lucas da PUCRS. All hospitalized patients with VRE positive culture were included and followed from their diagnosis until they were negative for VRE or their discharge. Only the first admission for each VRE positive patient was included. Pulsed field gel electrophoresis (PFGE) was performed to determine how VRE had spread.

Results: A total of 315 cases of VRE were identified, 224 of which were isolated from rectal swabs. Vancomycin-resistant/ampicilin susceptible Enterococcus faecalis were identified in 312 isolates. PFGE was performed in $47 \mathrm{VRE}$ isolates that presented an indistinguishable migratory profile. The median length of hospital stay and length of stay before VRE isolation were 46 days and 21 days, respectively; $52 \%$ of the patients were aged 60 and above. The annual distribution of the new VRE cases showed a clear decrease from 2000 to 2009.

Discussion: This study shows a substantial VRE colonization $(71 \%)$ with a homogenous pattern that emphasizes its transversal spread. Predominance of $E$. faecalis differs from the literature which largely describes a higher prevalence of vancomycin-resistant Enterococcus faecium. The follow up of VRE during 9 years in our institution highlighted the importance of continuous surveillance to prevent outbreaks in our hospital.

Keywords: Vancomycin-resistant Enterococcus, VRE, outbreak, surveillance.

Enterococci are normal inhabitants of the intestinal tract of humans and animals ${ }^{1}$. Their capacity to colonize the host for long periods of time, to survive in inanimate objects, and to be resistant to many commonly used antibiotics ensures their success as a nosocomial pathogen ${ }^{1-5}$. Enterococcus spp can cause serious infections such as bacteremia, urinary tract infection, endocarditis, and intra-abdominal infection, mainly in immunocompromised patients ${ }^{5}$. Among the Enterococcus species, Enterococcus faecalis and E. faecium are the most common, corresponding to $80-90 \%$ and $5-10 \%$ of clinical isolates, respectively ${ }^{1,5}$. This proportion has shifted somewhat as $E$. faecium has become increasingly resistant to antimicrobial agents and emerged as a major nosocomial pathogen ${ }^{6,7}$.

Infection with vancomycin-resistant Enterococcus (VRE) has been an increasing problem worldwide since the first reports in France and the United Kingdom in $1988^{8,9}$. VRE had spread rapidly throughout the world, particularly in the United States where $30 \%$ of the enterococci isolated from intensive
Clin Biomed Res. 2014;34(4):397-402

1 Infectious Diseases Service, Hospital São Lucas, Pontifícia Universidade Católica do Rio Grande do Sul, Porto Alegre, RS, Brazil.

2 Infection Control Service, Hospital São Lucas, Pontifícia Universidade Católica do Rio Grande do Sul, Porto Alegre, RS, Brazil.

3 Secretaria Municipal da Saúde de Santa Cruz do Sul, Santa Cruz do Sul, RS, Brazil.

4 Microbiology Unit, Department of Pathology, Hospital de Clínicas de Porto Alegre, Porto Alegre, RS, Brazil.

5 Biomedical Research Unit, Department of Pathology, Hospital de Clínicas de Porto Alegre, Porto Alegre, RS, Brazil.

Corresponding author:

Ana M. Sandri

E-mail: amsandri@terra.com.br Infectious Diseases Service Hospital São Lucas Pontifícia Universidade Católica do Rio Grande do Sul

Avenida Ipiranga, 6690 90610-000, Porto Alegre, RS, Brazi 
care units (ICUs) are resistant to vancomycin ${ }^{10-12}$. In Europe, infections caused by VRE are also a problem and correspond to $7 \%$ of the enterococcal isolates from blood culture; VRE are also important in the community and there is a relatively large reservoir of VRE that had been linked to the use of avoparcin in livestock ${ }^{13-15}$. In Brazil, the first case of VRE was reported in 1996, in Curitiba, and new cases were reported in the following year in the city of São Paulo and other cities ${ }^{16,17}$.

There are many risk factors for acquiring VRE: previous use of antibiotics, prolonged hospitalization, long ICU stay, immunossupression, and abdominal or thoracic surgery ${ }^{18,19}$. The spread of VRE in hospital settings has been widely reported and are usually due to: 1) patient-to-patient transmission, 2) hand contact of healthcare workers, or 3) contaminated environmental surfaces and medical equipment ${ }^{20-24}$.

The aim of the present study was to evaluate our local experience with VRE in Hospital São Lucas da Pontifícia Universidade Católica do Rio Grande do Sul (HSL/PUCRS), located in southern Brazil.

\section{METHODS}

\section{Patients and Setting}

The study was conducted at HSL/PUCRS, a 600 -bed tertiary care teaching institution located in the city of Porto Alegre, southern Brazil. The study population consisted of hospitalized patients with clinical or surveillance cultures positive for VRE. The study period was from May 2000, when VRE was isolated for the first time in our General Intensive Care Unit (GICU), through May 2009. Only one hospitalization per patient was considered. Outpatients were not included.

\section{Study Design}

We conducted a prospective cohort study including all hospitalized patients colonized and/or infected with VRE, who were followed up from the date of their diagnosis to the date they were negative for VRE or to their discharge from the hospital.

\section{Bacterial Culture and Identification}

Enterococci were obtained from clinical specimens or from rectal swabs during surveillance culture. Surveillance culture was performed once a week in patients admitted to the GICU, and at any time in patients who had shared a room with a VRE positive patient for more than 48 hours, according to the recommendations of the Infection Control Service (ICS) of our hospital.
The culture and identification of Enterococcus spp was performed according to conventional tests. The susceptibility of enterococci to vancomycin was evaluated using the disk diffusion method and followed the Clinical and Laboratory Standards Institute ${ }^{25}$. Results for isolates classified as resistant to vancomycin by the disk diffusion method were confirmed by the E-test method.

\section{Molecular Typing}

To determine how VRE had been spread, the genotypic profile of VRE isolates obtained from clinical specimens and rectal swabs was determined at the Biomedical Research Unit of the Clinical Pathology Service at Hospital de Clínicas de Porto Alegre (HCPA). Molecular typing was performed by DNA macrorestriction followed by pulsed field electrophoresis (PFGE) as previously described ${ }^{26}$. Briefly, unshared DNA was extracted from the bacterial culture and digested with Sma1 for 20 hours in a $30^{\circ} \mathrm{C}$ water bath. After digestion, the DNA fragments were subjected to PFGE in a CHEF-DR® II apparatus (Bio-Rad Laboratories, California, USA). In order to evaluate the discriminatory power of PFGE, vancomycinsusceptible Enterococcus spp (VSE) obtained from the same patients were also evaluated. The migratory profiles of the isolates were compared visually and analyzed according to the criteria of Tenover et al. ${ }^{27}$

\section{VRE Surveillance}

VRE positive patients were followed up from their diagnosis until they had two negative sequential swabs and clinical specimens with one week apart each other, or until their discharge from the hospital.

In order to prevent further spread of VRE, the ICS of our hospital established specific contact control measures according to the Guideline for Isolation Precautions in Hospitals, 1995, of the United States Centers for Diseases Control ${ }^{28}$. These precautions have been maintained from May 2000 to May 2009 and included active surveillance with weekly rectal swabs of GICU patients and control of all clinical materials from any unit of the hospital with identified cases of VRE. Positive patients, colonized and/or infected with VRE were subjected to weekly swabs and collection of clinical material; they were taken from the isolation when two subsequent swabs and clinical specimens were negative for VRE.

Once a patient was identified as being infected or colonized with VRE, he/she was put in a private room or in shared rooms with other VRE positive patients and advised not to visit common areas on the ward. Educational sessions were provided to all healthcare workers reinforcing contact precautions including hand hygiene, use of gloves and gowns, 
individualized equipments for each room (thermometers, stethoscopes, sphygmomanometers); in addition, if the patient traveled to another part of the hospital, he/she must be conducted in wheel chairs by the health team appropriately worn with gown and glove. Environmental cleaning procedures included daily cleaning of patient rooms and "terminal cleaning" at patient discharge. A sodium hypochlorite-based disinfectant was used for cleaning (Virex). The correct use of vancomycin was emphasized.

Only one hospitalization and one positive culture (the first to appear) per patient were considered.

\section{Statistical Analysis}

The statistical analyses were performed using SPSS, version 10.0. Results from descriptive statistics were presented in tables and graphics.

\section{RESULTS}

From May 2000 to April 2009, 315 cases of VRE were identified, of which 224 were isolated from rectal swabs and 91 from other clinical samples, mainly blood, followed by urine (table 1).

Table 1: VRE distribution according to the materials used for bacterial identification.

\begin{tabular}{lcr}
\hline \multicolumn{1}{c}{ Material } & $\mathbf{n}$ & \multicolumn{1}{c}{$\%$} \\
\hline Rectal swab & 224 & 71.11 \\
Blood culture & 36 & 11.43 \\
Urine culture & 29 & 9.21 \\
Others & 26 & 8.25 \\
Total & 315 & 100.00 \\
\hline
\end{tabular}

Strains of vancomycin resistant and ampicilin susceptible Enterococcus faecalis were identified in 312 isolates, of vancomycin and ampicilin resistant $E$. faecalis in 2 isolates, and of vancomycin and ampicilin resistant Enterococcus faecium in 1 isolate. Molecular typing was done in $47 \mathrm{VRE}$ isolates, 37 of which were from a rectal swab, 5 from secretion, 4 from blood, and 1 from urine. A well-defined DNA migratory profile could be observed for 46 VRE isolates, as only one did not migrate. The comparison of DNA profiles indicated that 39 isolates were indistinguishable, as there was no visible difference between the bands. This profile was designated profile "A". Four isolates presented migratory profiles closely related to profile "A", differing from it in only two bands (genotype A1, three isolates) and in three bands (genotype A2, one isolate). Three other isolates presented migratory profiles that were different from profile "A" by more than seven bands and were designated profiles "B", " $C$ " and " $D$ ". The discriminatory power of PFGE was evaluated by comparing VRE and VSE isolates obtained from the same patients. VSE isolates presented totally different migratory profiles when compared to clone $\mathrm{A}$.

The annual distribution of new VRE cases showed a clear decrease from 2000 to 2009 in Intensive Care Units (ICUs) and hospital wards (figure 1). The first cases identified at the beginning of 2000 were admitted to the GICU, but the outbreak extended to five different units: clinical and surgical unit, postcardiac surgical ICU, coronary ICU, pediatric ICU and post-surgical recovery unit (table 2).

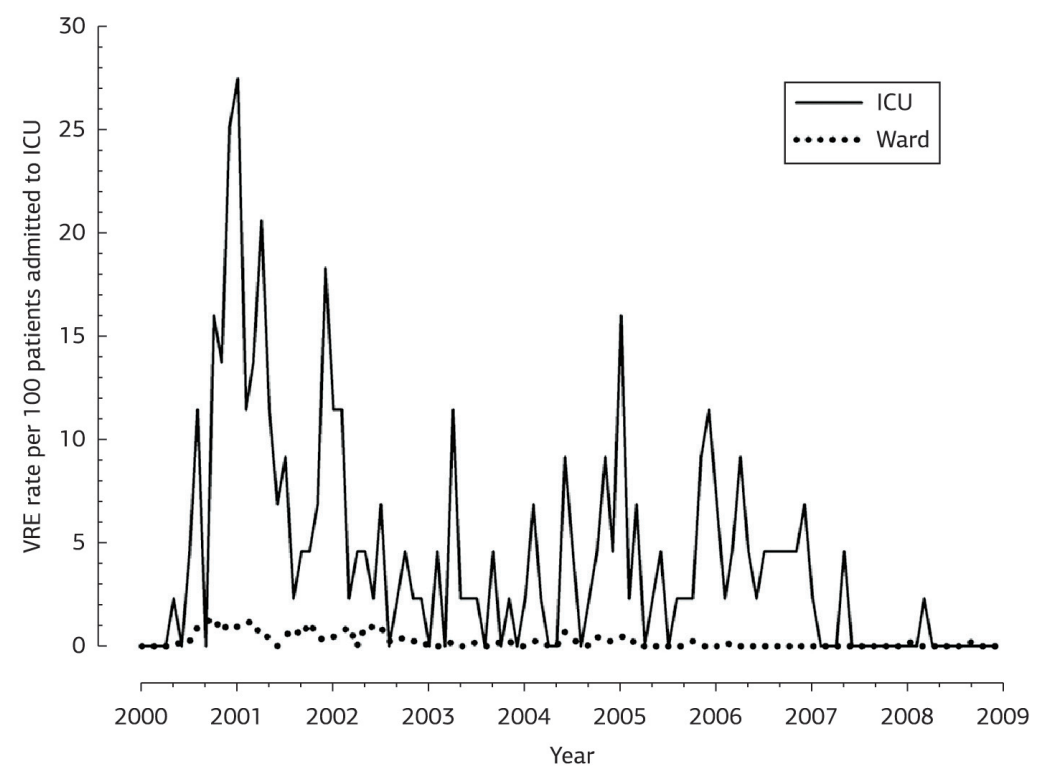

Figure 1: Distribution of the new VRE cases in the ICUs (straight line) and hospital wards (dotted line) from 2000 to 2009. 
Table 2: VRE distribution according to the units of hospitalization.

\begin{tabular}{lcc}
\hline \multicolumn{1}{c}{ Unit } & $\mathbf{n}$ & $\mathbf{( \% )}$ \\
\hline GICU $^{*}$ & 171 & 54.28 \\
Clinical and surgical unit & 113 & 35.87 \\
Post-cardiac surgical ICU** & 5 & 1.59 \\
Coronary ICU & 20 & 6.35 \\
Pediatric ICU & 3 & 0.95 \\
Post-surgical unit & 3 & 0.95 \\
Total & 315 & 100.00 \\
\hline${ }^{*}$ GICU= General Intensive Care Unit ; ${ }^{* *} \mathrm{ICU}=$ Intensive Care Unit.
\end{tabular}

Table 3: VRE distribution according to patients' age.

\begin{tabular}{ccc}
\hline Age & $\mathbf{n}$ & $\mathbf{( \% )}$ \\
\hline $0 \dashv 19$ & 15 & 4.8 \\
$20 \dashv 39$ & 56 & 17.8 \\
$40-59$ & 80 & 25.4 \\
$60 \dashv$ & 164 & 52.0 \\
Total & 315 & 100.0 \\
\hline
\end{tabular}

The median time of hospitalization was 46 days ( 1 to 393 days) and the median time of hospitalization before VRE was isolated for the first time was 21 days ( 1 to 366 days). People over 60 years were the most affected (table 3 ).

\section{DISCUSSION}

This study demonstrates substantial VRE colonization $(71.1 \%)$ in patients admitted to our hospital as assessed by rectal swab; among the clinical materials used for bacterial identification, blood and urine were the most important. The indistinguishable profile observed for the vast majority of the VRE isolates in PFGE indicates a transversal environmental mode of spread. Our results are consistent with earlier studies that indicated clonal dissemination as a major mechanism for spreading of isolates ${ }^{20-22}$. However, the absolute predominance $(99.68 \%$ ) of $E$. faecalis among VRE cases during the period of the study is not consistent with what has been reported in the literature, which largely describes a higher prevalence of vancomycin resistant E. faecium ${ }^{29-32}$. Studies from Porto Alegre, Southern Brazil, also demonstrated the important occurrence of vancomycin-resistant $E$. faecium during recent years ${ }^{33}$. The predominance of VRE in older people and in ICUs are also observed in literature. The incidence distribution curve for VRE in our hospital shows that it almost disappeared throughout the 9-year period observed. The implementation of specific and persistent infection control measures probably played a crucial role in these results as we can observe in many publications $\mathrm{s}^{23,24,34-38}$.

In conclusion, following the VRE pattern across a 9-year period allowed us to learn how to deal with these resistant bacteria and to understand that its presence can be an excellent indication of the capacity of the unit to maintain the safety measures to avoid the cross transmission of the microorganisms. Continuous surveillance of VRE is mandatory due to its clinical and epidemiologic importance, in order to promptly implement specific control measures to prevent new outbreaks.

\section{REFERENCES}

1. Murray BE. The life and times of the Enterococcus. Clin Microbiol Rev. 1990;3(1):46-65. PMid:2404568.

2. Facklam RR, Carvalho MG, Teixeira L. History, taxonomy, biochemical characteristics, and antibiotic susceptibility testing of enterococci. In: Gilmore MS, editor. The enterococcipathogenesis, molecular biology, and antibiotic resistance. Washington, DC: ASM Press; 2002. p. 1-54.

3. Moellering RC JR. Emergence of Enterococcus as a significant pathogen. Clin Infect Dis. 1992;14(6):1173-8. http://dx.doi. org/10.1093/clinids/14.6.1173. PMid:1623072

4. Chavers LS, Moser SA, Benjamin WH JR, Banks SE, Steinhauer JR, Smith AM, et al. Vancomycin-resistant enterococci: 15 years and counting. $J$
Hosp Infect. 2003;53(3):159-71. http:// dx.doi.org/10.1053/jhin.2002.1375. PMid:12623315

5. Moellering RC JR. Vancomycinresistant enterococci. Clin Infect Dis. 1998;26(5):1196-9. http://dx.doi. org/10.1086/520283. PMid:9597252

6. Edmond MB, Wallace SE, McClish DK, Pfaller MA, Jones RN, Wenzel RP. Nosocomial bloodstream infections in United States hospitals: a three-year analysis. Clin Infect Dis. 1999;29(2):239-44. http://dx.doi. org/10.1086/520192. PMid:10476719

7. Reik R, Tenover FC, Klein E, McDonald LC. The burden of vancomycin-resistant enterococcal infections in US hospitals, 2003 to 2004. Diagn Microbiol Infect Dis. 2008;62(1):815. http://dx.doi.org/10.1016/j. diagmicrobio.2008.04.013. PMid:18508225

8. Uttley $\mathrm{AH}$, Collins $\mathrm{CH}$, Naidoo J, George RC. Vancomycin-resistant enterococci. Lancet. 1988;331(85758576):57-8. http://dx.doi.org/10.1016/ S0140-6736(88)91037-9. PMid:2891921

9. Leclercq R, Derlot E, Duval J, Courvalin P. Plasmid-mediated resistance to vancomycin and teicoplanin in Enterococcus faecium. N Engl J Med. 1988;319(3):15761. http://dx.doi.org/10.1056/ NEJM198807213190307. PMid:2968517

10. Ofner-Agostini M, Johnston BL, Simor AE, Embil J, Matlow A, Mulvey M, et al, Vancomycin-resistant enterococci in Canada: results from the Canadian nosocomial infection surveillance 
program, 1999-2005. Infect Control Hosp Epidemiol. 2008;29(3):271-4. http://dx.doi.org/10.1086/528812. PMid:18241031

11. Ramsey AM, Zilberberg MD. Secular trends of hospitalization with vancomycin-resistant enterococcus infection in the United States, 20002006. Infect Control Hosp Epidemiol. 2009;30(2):184-6. http://dx.doi. org/10.1086/593956. PMid:19125679

12. National Nosocomial Infections Surveillance System. National Nosocomial Infections Surveillance (NNIS) System Report, data summary from January 1992 through June 2004, issued October 2004. Am J Infect Control. 2004;32(8):47085. http://dx.doi.org/10.1016/j. ajic.2004.10.001. PMid:15573054

13. Rossolini GM, Mantengoli E. Antimicrobial resistance in Europe and its potential impact on empirical therapy. Clin Microbiol Infect. 2008;14(Suppl 6):2-8. http://dx.doi.org/10.1111/j.14690691.2008.02126.x. PMid:19040461

14. Kühn I, Iversen A, Finn M, Greko C, Burman LG, Blanch AR, et al. Occurrence and relatedness of vancomycin-resistant enterococci in animals, humans, and the environment in different European regions. Appl Environ Microbiol. 2005;71(9):5383-90. http://dx.doi. org/10.1128/AEM.71.9.53835390.2005. PMid:16151128

15. Gambarotto K, Ploy MC, Turlure P, Grélaud C, Martin C, Bordessoule $\mathrm{D}$, et al. Prevalence of vancomycinresistant enterococci in fecal samples from hospitalized patients and nonhospitalized controls in a cattle-rearing area of France. $J$ Clin Microbiol. 2000;38(2):620-4. PMid:10655356.

16. Dalla Costa LM, Souza DC, Martins LT, Zanella RC, Brandilone MC, Bokermann S, et al. Vancomycinresistant Enterococcus faecium: first case in Brazil. Braz $J$ Infect Dis. 1998;2(3):160-3. PMid:11103003.

17. Zanella RC, Valdetaro F, Lovgren M, Tyrrel GJ, Bokermann S, Almeida $\mathrm{SC}$, et al. First confirmed case of a vancomycin-resistant Enterococcus faecium with vanA phenotype from Brazil: isolation from a meningitis case in São Paulo. Microb Drug Resist. 1999;5(2):159-62. http:// dx.doi.org/10.1089/mdr.1999.5.159. PMid:10432277
18. Carmeli Y, Eliopoulos GM, Samore $\mathrm{MH}$. Antecedent treatment with different antibiotic agents as a risk factor for vancomycin-resistant Enterococcus. Emerg Infect Dis. 2002;8(8):802-7. http://dx.doi. org/10.3201/eid0808.010418. PMid:12141965

19. Harbarth S, Cosgrove S, Carmeli Y. Effects of antibiotics on nosocomial epidemiology of vancomycin-resistant enterococci. Antimicrob Agents Chemother. 2002;46(6):161928. http://dx.doi.org/10.1128/ AAC.46.6.1619-1628.2002. PMid:12019066

20. Hayden MK, Blom DW, Lyle EA, Moore CG, Weinstein RA. Risk of hand or glove contamination after contact with patients colonized with vancomycin-resistant enterococcus or the colonized patients' environment. Infect Control Hosp Epidemiol. 2008;29(2):149-54. http://dx.doi. org/10.1086/524331. PMid:18179370

21. Duckro AN, Blom DW, Lyle EA, Weinstein RA, Hayden MK. Transfer of vancomycin-resistant enterococci via health care worker hands. Arch Intern Med. 2005;165(3):302-7. http:// dx.doi.org/10.1001/archinte.165.3.302. PMid:15710793

22. Snyder GM, Thom KA, Furuno JP, Perencevich EN, Roghmann MC, Strauss SM, et al. Detection of Methicillin-Resistant Staphylococcus aureus and Vancomycin-Resistant Enterococci on the Gowns and Gloves of Healthcare Workers. Infect Control Hosp Epidemiol. 2008;29(7):583-9. http://dx.doi.org/10.1086/588701. PMid:18549314

23. Lankford MG, Collins S, Youngberg L, Rooney DM, Warren JR, Noskin GA. Assessment of materials commonly utilized in health care: implications for bacterial survival and transmission. Am J Infect Control. 2006;34(5):25863. http://dx.doi.org/10.1016/j. ajic.2005.10.008. PMid:16765202

24. Boyce JM. Environmental contamination makes an important contribution to hospital infection. $J$ Hosp Infect. 2007;65(Suppl 2):50-4. http://dx.doi.org/10.1016/S01956701(07)60015-2. PMid:17540242

25. Clinical and Laboratory Standards Institute. Performance standards for antimicrobial susceptibility testing; twenty first informational supplement. Document M100-S21. Wayne: Clinical and Laboratory
Standards Institute; 2011.

26. Kaufmann ME. Pulsed-field gel electrophoresis. In: Woodford N, Johnson AP, editors. Molecular bacteriology, protocols and clinical applications. New Jersey: Humana Press Inc; 1998. p. 33-62.

27. Tenover FC, Arbeit RD, Goering RV, Mickelsen PA, Murray BE, Persing $\mathrm{DH}$, et al. Interpreting chromosomal DNA restriction patterns produced by pulsed-field gel electrophoresis: criteria for bacterial strain typing. $J$ Clin Microbiol. 1995;33(9):2233-9. PMid:7494007.

28. Hospital Infection Control Practices Advisory Committee (HICPAC). Recommendations for preventing the spread of vancomycin resistance. Recommendations of the Hospital Infection Control Practices Advisory Committee (HICPAC). MMWR Recomm Rep. 1995;44(RR-12):1-13. PMid:7565541.

29. Zhanel GG, DeCorby M, Laing N, Weshnoweski B, Vashisht R, Tailor $\mathrm{F}$, et al. Antimicrobial-resistant pathogens in intensive care units in Canada: results of the Canadian National Intensive Care Unit (CANICU) study, 2005-2006. Antimicrob Agents Chemother. 2008;52(4):14307. http://dx.doi.org/10.1128/ AAC.01538-07. PMid:18285482

30. Hayden MK. Insights into the epidemiology and control of infection with vancomycin-resistant enterococci. Clin Infect Dis. 2000;31(4):1058-65. http://dx.doi.org/10.1086/318126. PMid:11049790

31. Młynarczyk G, Grzybowska W, Młynarczyk A, Tyski S, Kawecki D, Łuczak M, et al. Significant increase in the isolation of glycopeptideresistant enterococci from patients hospitalized in the transplant surgery ward in 2004-2005. Transplant Proc. 2007;39(9):28835. http://dx.doi.org/10.1016/j. transproceed.2007.08.045. PMid:18022008

32. Cohen MJ, Adler A, Block C, Gross I, Minster N, Roval V, et al. Acquisition of vancomycin-resistant enterococci in internal medicine wards. Am J Infect Control. 2009;37(2):111-6. http:// dx.doi.org/10.1016/j.ajic.2008.04.260. PMid:18986736

33. Resende M, Caierão J, Prates JG, Narvaez GA, Dias CAG, d'Azevedo PA. Emergence of vanA vancomycin- 
resistant Enterococcus faecium in a hospital in Porto Alegre, South Brazil. J Infect Dev Ctries. 2014;8(2):160-7. http://dx.doi.org/10.3855/jidc.4126. PMid:24518625

34. Kurup A, Chlebicki MP, Ling ML, Koh TH, Tan KY, Lee LC, et al. Control of a hospital-wide vancomycin-resistant Enterococci outbreak. Am J Infect Control. 2008;36(3):206-11. http:// dx.doi.org/10.1016/j.ajic.2007.06.005. PMid:18371517

35. Hayden MK, Bonten MJ, Blom DW, Lyle EA, van de Vijver DA, Weinstein $R A$. Reduction in acquisition of vancomycin-resistant Enterococcus after enforcement of routine environmental cleaning measures. Clin Infect Dis. 2006;42(11):1552-60. http://dx.doi.org/10.1086/503845. PMid:16652312

36. Hota B, Blom DW, Lyle EA, Weinstein RA, Hayden MK. Interventional evaluation of environmental contamination by vancomycinresistant enterococci: failure of personnel, product, or procedure? J Hosp Infect. 2009;71(2):123-31. http:// dx.doi.org/10.1016/j.jhin.2008.10.030. PMid:19108932
37. Mascini EM, Troelstra A, Beitsma M, Blok HE, Jalink KP, Hopmans $\mathrm{TE}$, et al. Genotyping and preemptive isolation to control an outbreak of vancomycin-resistant Enterococcus faecium. Clin Infect Dis. 2006;42(6):739-46. http://dx.doi. org/10.1086/500322. PMid: 16477546

38. Tacconelli E, Cataldo MA. Vancomycin-resistant enterococci (VRE): transmission and control. Int J Antimicrob Agents. 2008;31(2):99106. http://dx.doi.org/10.1016/j. ijantimicag.2007.08.026. PMid:18164908 